\title{
Competences in Teacher Education at Schwyz University of Teacher Education (PHSZ), and the Swiss Education Policy
}

\author{
Illya Arnet-Clark, Rosemary Smeets-Cowan, \\ Jürgen Kühnis
}

\begin{abstract}
Based on the current discussion on $21^{\text {st }}$ century skills this contribution gives a short overview of the present situation in Switzerland and at $\mathrm{PHSZ}^{1}$ in particular. What are the aims of education policy and what has already been achieved in this process? As this analysis has shown, the biggest challenge is to ensure a smooth and timely educational paradigm shift to competence orientation at universities of teacher education and schools. This means a change from teaching factual knowledge to the development of competences needed to acquire the necessary knowledge in a fast-changing society. This gradual integration is challenging and requires basic adaptations to the curriculum and to the current teacher education and teaching practice. The new Curriculum 21 has been developed to take on this challenge through all school levels.
\end{abstract}

Key words: $21^{\text {st }}$ century skills, competences, Curriculum 21, teacher education, PHSZ, Switzerland

\footnotetext{
1 Pädagogische Hochschule Schwyz; http://www.phsz.ch
} 


\section{Introduction}

What competences does the next generation need und how can they be taught adequately to young learners? In our fast-changing and globalized world and in light of the complex challenges of our society such questions are of central interest. In the last decade, the implementation of competence-oriented education and the evaluation of the output of educational processes have become a central topic and primary concern in the international and national context as well (Rychen \& Salganik, 2003; OECD, 2005; Ananiadou \& Claro 2009).

These educational endeavours are also a central topic in the Swiss education system. For this reason, the Swiss-German Conference of Cantonal Ministers of Education (D-EDK) worked on a common competence-oriented curriculum for all of the Germanspeaking cantons ${ }^{2}$ (D-EDK, 2014a) from 2010-2014 to harmonise both state education (kindergarten to secondary level) and pre-service and in-service teacher training. Each individual canton can now decide on when the curriculum will be introduced; according to current information, most of the cantons plan this implementation between 2017 and 2019 (D-EDK, 2014a, p. 15).

Teacher education is mainly the task of the universities of education throughout Switzerland, including the Schwyz University of Education (PHSZ). Located in Central Switzerland, PHSZ is one of the smallest of these institutions with approximately 320 students, and may be considered as exemplary for other smaller institutes. With this background in mind, this article sets out to locate $21^{\text {st }}$ century skills within the key competences as used in the current paradigm shift of the Swiss Curriculum 21, in the education of primary school teachers and research at the Schwyz University of Teacher Education.

\section{Framing the meaning of $21^{\text {st }}$ century skills in a Swiss context}

There are many definitions of $21^{\text {st }}$ century skills, which can be interpreted with different headings and nuances depending on country and institution. The four core Cs lie at the heart of these skills: Critical thinking, communication, collaboration, and creativity. Whereas the term ' $21^{\text {st }}$ century skills' is widely used, in a Swiss context this term is rarely encountered. Instead 'competences' is the current buzz word which can be found in the main education-related documents used for coordinating Curriculum 21, the

2 The French speaking cantons have developed a comparable curriculum with the'PER' (Plan d'Études Romand) (http://www.plandetudes.ch/per); in the Italian speaking canton, Ticino, the curriculum is currently being revised. 
Organisation for Economic Co-operation and Development (OECD) documents, and regional documents such as those from the PHSZ.

According to OECD (Ananiadou \& Claro, 2009, p. 8) the difference between skills and competences is described as follows: "A competence is more than just knowledge or skills. It involves the ability to meet complex demands, by drawing on and mobilising psychosocial resources (including skills and attitudes) in a particular context. For example, the ability to communicate effectively is a competence that may draw on an individual's knowledge of language, practical IT skills and attitudes towards those with whom he or she is communicating." (Rychen \& Salganik, 2003). Thus it becomes clear that by focusing on competences, a wider dimension is addressed.

The OECD $(2005$, p. 5) defines three categories of key competencies: interacting in socially heterogeneous groups, acting autonomously, and using tools interactively, all necessary prerequisites for a successful life. In a further document the OECD (2013, p. 46) stresses that these skills need to be developed, activated and put to effective use. Each key competency must fulfill the following (OECD 2005, p. 4): "Contribute to valued outcomes for societies and individuals; help individuals meet important demands in a wide variety of contexts; and be important not just for specialists but for all individuals." $21^{\text {st }}$ century skills imply the ability to reach beyond knowledge and skills in order to better "tackle complex tasks" (OECD, 2005, p. 8) and master the growing demands of our ever-changing society.

For the purposes of this article in a Swiss context the definition of $21^{\text {st }}$ century skills will be integrated into the term 'competences' as it becomes clear that by focusing on these, a wider dimension which integrates skills is addressed. The Swiss Curriculum 21 orients itself on the definition described by Weinert (2001, p. 27) as such:The learnable or acquired cognitive skills and abilities which are necessary to solve certain problems, as well as the motivational, volitional and social readiness to do so successfully in a variety of situations. (article author's translation). Reusser (2014, p. 327) goes on to add that competences not only stand for a connection between level-appropriate subject knowledge, content- and process-related ability and skills, but also a willingness and readiness to reflect, and to develop strategies in the different areas in order to grow. According to $\operatorname{OECD}(2005$, p. 9) reflectiveness is at the heart of this process, implying "... the use of metacognitive skills (thinking about thinking), creative abilities and taking a critical stance." 


\section{The Swiss Curriculum 21 and the Competences}

One of the key factors currently affecting the curriculum at the PHSZ, and indeed throughout all of the German-speaking part of Switzerland, is the introduction Curriculum 21 . The 21 may symbolically stand for $21^{\text {st }}$ century skills, or a curriculum for the $21^{\text {st }}$ century, but in effect, the number 21 represents the number of German-speaking cantons which will implement the new curriculum. As Switzerland is a highly federalist country, to date each canton has had the authority to develop its own separate curriculum. The new curriculum is meant to unite these 21 cantons educationally (D-EDK, 2014a, p. 4), and in doing so, account for the global state of the world and migration within Switzerland. It has, in fact, not been without resistance that Curriculum 21 is currently being introduced and adopted in the different cantons, and some will soon be voting on whether to adopt this "restrictive" curriculum or not.

As of writing, the canton of Schwyz, for which the PHSZ primarily trains future teachers, has not yet decided which path to follow. However, the Curriculum 21 is already having an influence on the training of future teachers at all the universities of primary and secondary education, including the PHSZ. Curriculum 21 states which subjects and interdisciplinary competences, described in terms of skills and abilities, are to be covered during compulsory schooling from kindergarten to secondary level (see figure 1). The basic requirements, points of orientation and consequent competence levels will be described for each cycle for the six subject areas (languages, mathematics, general science and social studies, art-craft-design, music and physical education). In each subject description the competences are clearly defined and linked, where appropriate, to other subjects and/or further competences. Interdisciplinary, personal, methodological and social competences (e.g. critical thinking and reflection) are linked to subject-specific competences (D-EDK, 2014b, p. 13-16).

This format results in more transparency as to where different subjects are linked, making it easier to develop a better network of information between the individual subjects and encourage cross-curricular teaching (D-EDK, 2014b, p. 6-7). One such example is the link between foreign languages and German, the school language D-EDK, 2015 a, p. 1). It is explicitly stated in Curriculum 21 that learners should be able to transfer learning strategies from their first language of instruction ${ }^{3}$ to foreign language instruction and by doing so, further strengthen their understanding of the school language. Communicative competence and cultural tolerance are further aims found in the general subject of language, forming a common theme throughout the languages.

3 In the German speaking part of Switzerland regional dialects are spoken. These are diverse and can vary considerably to 'standard' German, the language of school instruction. For this reason many people consider 'standard' German to be the first foreign language. 


\section{Figure 1}

Overview of the cycles and subject areas (D-EDK, 2014a, p. 11)

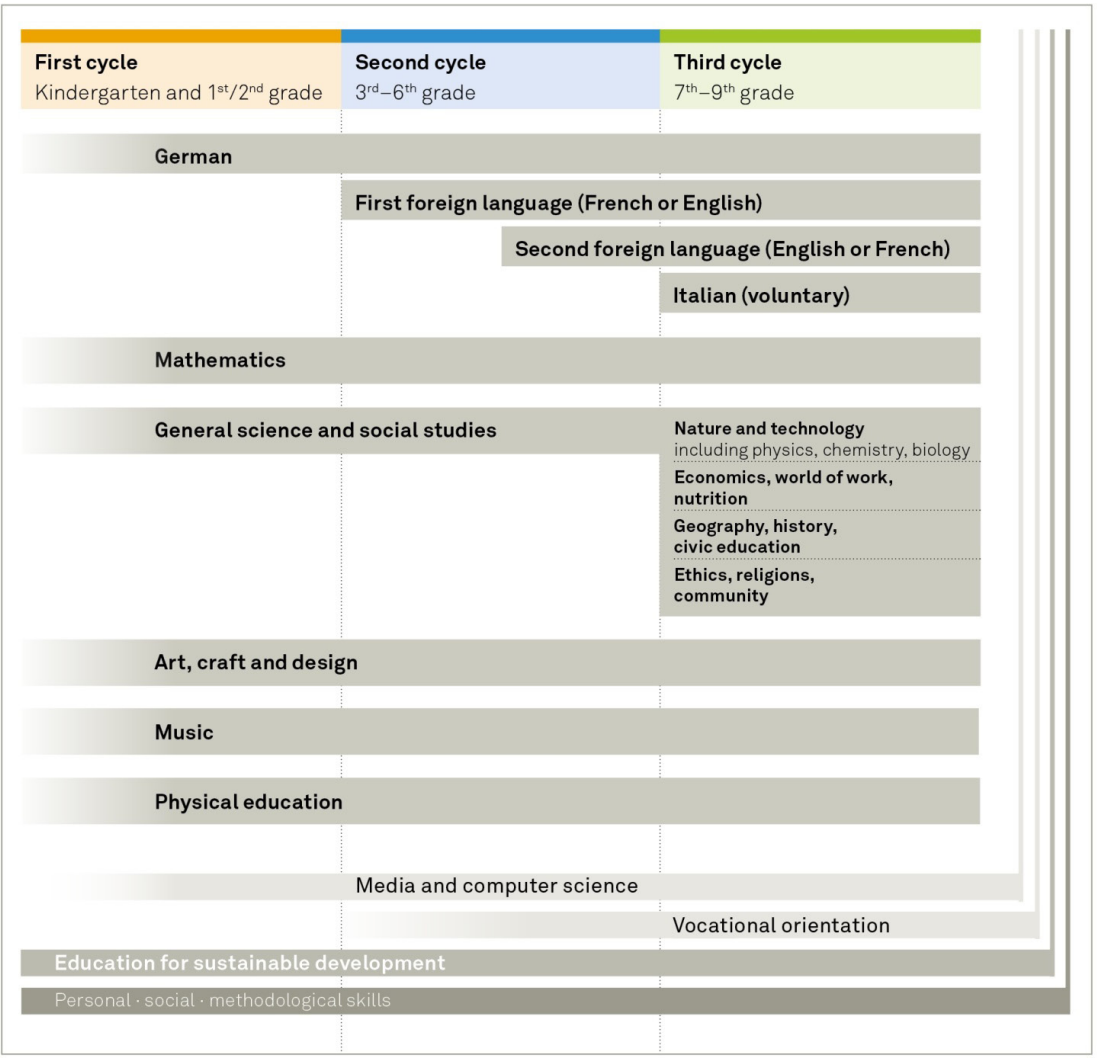

Note: The translation of the original German version was made in cooperation with the D-EDK.

The most obvious skills relating to $21^{\text {st }}$ century skills are found in the curricular module media and computer science (D-EDK, 2014c). The curriculum differentiates between the areas of competency in media and computer science, and competences in the usage of information and communication technology for learning purposes, every day usage and for future professional work and development (see figure 2). While media und computer science are taught as an individual subject, computer literacy is applied in the six main subjects mentioned above. Soft skills such as social competence and the ability to communicate and participate in a digitally global world using a variety of tools and devices (D-EDK, 2014c, p. 2), including those which have yet to be developed, are 
integral in media and computer science, forming a further important focus. These skills are a central area of research at the PHSZ and will be described in more detail further on.

Through vocational orientation, the second interdisciplinary subject, young people should acquire competences necessary for their vocational education and further schooling. This field of study helps learners develop important $21^{\text {st }}$ century skills for their adult life, with the main focus in the third cycle building bridges between public schooling and apprenticeship, which include the four competence areas (D-EDK, 2015b, p. 1-2): development of learners' personalities; preparation for the working world; decision-making and dealing with conflict; and planning, implementation and documentation.

With the introduction of the new curriculum, education for sustainable development (ESD) ${ }^{4}$ will also become a compulsory part of the Swiss educational system (see figure 1). ESD stands for a holistic principle, and interdisciplinary education concept which "... empowers learners to take informed decisions and responsible actions for environmental integrity, economic viability and a just society for present and future generations, while respecting cultural diversity." (UNESCO 2014b, p. 12). To achieve these competencies, children must be made aware of sustainability at an early age by focusing on cross-curricular topics (D-EDK, 2014b, p. 17-18). Thanks to the different specialist groups, "foundation education 21" as national competence and service centre ${ }^{5}$, plus existing didactic materials (Künzli et al., 2008; Muheim et al., 2014) ESD is already anchored in Swiss education.

\section{Figure 2}

Structure of curricular module media and computer science (D-EDK 2014c, p. 6)

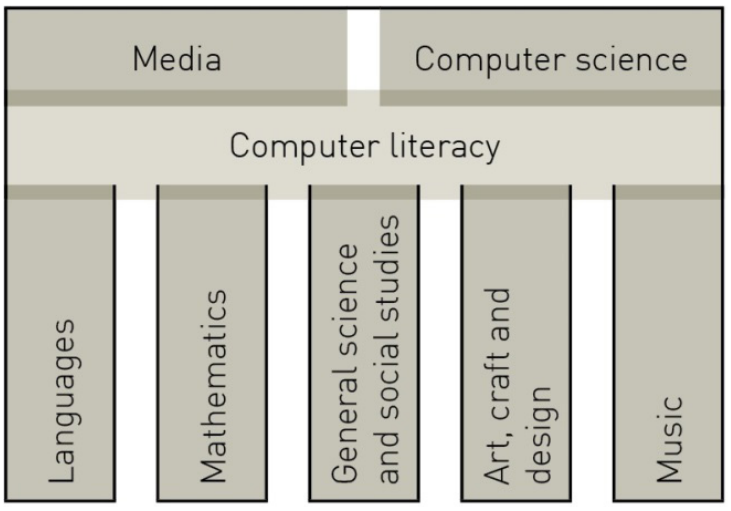

4 Since the UN decade 2005-2014, the ESD has become a worldwide central educational concern (UNESCO 2014a).

5 htpp://www.education21.ch 


\subsection{Implementation of change at PHSZ}

\section{The training approach}

In order for teachers to acquire or strengthen their own key competences and help their learners acquire them, work needs to be done in teacher education. In accordance with the European Bologna Declaration of $1999^{6}$ and European Qualification Framework ${ }^{7}$, changes in the methodology are being advanced and implemented at a national level in order to better prepare future teachers for $21^{\text {st }}$ century education. The shift from teaching to learning, described by Barr and Tagg as early as 1995, has since become a mantra in teacher education. The focus is no longer simply on factual knowledge and how to transfer it to the learners, but on promoting inquiry, critical thinking and reflection of the future teachers. In the OECD document "Preparing teachers and Developing School Leaders for the $21^{\text {st }}$ Century" the necessity of the change in focus in teacher education is described as such:"A generation ago, when teachers could reasonably expect that what they taught would last for a lifetime, teaching a fixed syllabus of content was at the centre of education in most countries. Today, where individuals can access content on search engines, where routine rule based knowledge is being digitalised or outsourced, and where jobs are changing rapidly, teachers need to enable people to become lifelong learners, to manage non-rule-based complex ways of thinking and complex ways of working that computers cannot take over easily" (Schleicher, 2012, p. 35).

Teachers also need to be prepared for lifelong learning: "In short, the kind of education needed today requires teachers to be high-level knowledge workers who constantly advance their own professional knowledge as well as that of their profession." (Schleicher, 2012, p. 36) and so the training needs to help future teachers develop these skills. This is where the shift from teaching to learning becomes an important element in teacher education (Wildt, 2005, p. 2). In the area of critical and inquiry-based teaching the PHSZ has taken a dedicated step to include problem- or project- based learning (PBL) as an integral method of training, thereby encouraging autonomous learning. The theoretical basis of this approach is derived from a constructivist view of learning. Through their personal experience with this approach, strengthened through reflection of their own learning process, it is hoped that these future teachers in turn will be more adept and willing to apply such an approach in their own classrooms.

To account for the change of approach PBL requires, the attendance requirements have changed to allow students time for self-organized learning, giving them time to ask, research, and answer study-related questions. The methodology is being taught in the form of the "didactic double-decker": do-reflect-transfer, so that students will have the necessary experience and reflection to be able to use it for their own primary

6 http://www.ehea.info

http://www.eqf-ref.eu 
school classes. The time necessary for such an approach is also accounted for in the semester timetables, and supported through the use of blended and on-line content.

Intercultural competences are important in our globalised world, and especially so in a multilingual country like Switzerland, which is by nature multi-cultural with its four national languages ${ }^{8}$. Multi-lingual and cultural exchange programmes are fully supported at PHSZ and all students studying to become primary school teachers are required to do a three week assistant teachership in either an English-speaking or French-speaking region. These exchanges plus a four week language stay abroad enable students to gain an insight into another school system and expand their cultural knowledge of the country whose language they will be teaching and are both requisites of Curriculum 21 and the competences required in language teaching (Hutterli, 2012).

\subsection{Participation in international projects}

Since its beginnings, PHSZ has played an active part in European projects, especially important to date to keep its voice in Europe and to maintain the contacts with its partners. PHSZ has participated in EU Comenius projects such as FACE IT (2007-2009), ETSize (2010-2011) and VoiceS (2012-2015). Taking part in similar projects in the future might contribute to achieving some of the goals stipulated in Curriculum 21, in particular with relation to the section on the first foreign language English in canton Schwyz, FA1E.5 (Language(s) in Focus), Awareness of linguistic diversity and FS1E.6 Cultures in Focus. Although the lingua franca of these EU projects is English, communicating with the partner countries in their own language is beneficial, mutually rewarding and positively looked on with a view to plurilingualism, which is an important aspect in the coordination of language teaching in Switzerland (Hutterli, 2012). These projects will most certainly play a role in encouraging tolerance in the students and helping them nurture a tolerant attitude in their own classes.

\section{Examples of research in digital media}

The Institute for Media in Schools (IMS) is the research department within the PHSZ. As its name suggests, IMS places a strong focus on the use of digital media and how the development of competences to facilitate teaching and learning processes in this field can be furthered in the classroom to prepare children best to live in the information society. It also considers the implications for universities of teacher education. However, implementation is only slowly taking place in the primary classroom. In recent

8 Switzerland's four official languages ranked by number of speakers: German, French, Italian and Romansch (a derivative of Latin). In all regions two foreign languages are taught from primary school, at least one of which must be an official language. The other foreign language is usually English. 
years it has been examining questions of this kind through a series of projects, funded by Swiss National Science Foundation and other partners. Apart from many empirical projects, it has been developing practical solutions and methods for schools. Below is a short selection which illustrates how key competences in digital media and literacy are being researched.

For some years now, the Institute for Media and Schools has been working in collaboration with the Goldau primary school ${ }^{9}$ to examine its activities in daily school practice. Since 2009 the project school has been experimenting with the potential uses of smartphones in teaching and learning and has been extended to cover the use of BYOD (Bring your own device) (Döbeli Honegger \& Neff, 2011).

With support from the Swiss National Science Foundation, IMS has been conducting a series of quasi-experimental studies to determine the conditions under which the use of computer games for classroom instruction results in increased motivation and engagement with the instructional content. It is specifically investigating the importance of collateral learning tasks and teacher support for the learning process using games. One such research project conducted by IMS, Awwware. $\mathrm{CH}^{10}$, is a browser-based online game to promote media competency in children and adolescents and to examine the use of 'serious games' in instruction and its effect on both cognitive and motivational learning gains. Its findings revealed that the fun aspect when learning with computer games played a smaller role than previously expected (Iten \& Petko, 2014).

IMS's work is based on established theories and problem-solving approaches, but also applies specifically relevant development methods and uses empirical procedures to test their solutions in actual practice. For a long time, pedagogical development was mainly regarded as an application field for discoveries made in educational research. Today, the boundaries between basic and applied research are much more fluid. In this regard, the "design-based research" approach to development has shown great promise for stimulating theory building. PHSZ regularly holds digital state-of-the art conferences presenting the latest projects by leading speakers from Switzerland and abroad. For example, the conference from May 2015 entitled 'Do IT yourself' discusses the competences defined in media and computer science in Curriculum 21 and how to implement them in the classroom.

\section{Conclusions}

Although the term " $21^{\text {st }}$ century skills" is not mentioned in any official national document nor within the PHSZ, by looking at the examples presented in teacher education, international projects and research it is possible to locate the key competences and

9 For detailed information (but only in German) see the website http://www.projektschule-goldau.ch

$10 \mathrm{http}: / /$ www.awwware.ch 
find elements of $21^{\text {st }}$ century skills in the PHSZ teacher education programme and in its realisation of the new curriculum with the change in paradigm. In the context of teacher education at PHSZ, classroom practice is implemented and assessed in these areas. As such, this is not the area of resistance and students are generally open to innovation and change as they have not yet become set in their ways. They are given ample time for their teaching practicum and are supported both by a practising teacher and a mentor from PHSZ. There is a continuous cycle of reflection parallel to their teaching experience.

However, the major challenge with which PHSZ is confronted is the integration of these skills into primary school education. This change requires a more cross-curricular approach in order to draw on the interdisciplinary competences in enquiry and critical thinking, reflection, and social skills (D-EDK, 2014b, p. 13). New course books, different teaching methods, and, most difficult of all, a wider set of competences for the teachers will be necessary. Constructive feedback and a focus on how far the learners' competences have developed will build a stark contrast to the current 'error culture'11.

With practising teachers, especially those with many years of experience, there is a tendency to reject wide-reaching change. Teachers use much of their time and energy to be trained in areas where they may or may not see the relevance. In order to coordinate the new Curriculum 21 successfully throughout the canton of Schwyz, a strategy has been developed in which the introduction and implementation is supported not just from the top, but directly from within the ranks of the teachers. This means that the necessary support and qualification of teachers must cover two subsequent areas: both the individual ability for competence-based teaching, and the collective professionalisation of each school for the mutual realisation of the curriculum (Lersch \& Schreder, 2013 , p. 27). For this reason lecturers and staff from PHSZ will train a group of volunteers such as teachers, heads of schools, and advisors; the latter will then develop and test materials in school settings. These materials will be used in the next stage of training the teachers. It is assumed that by reducing the 'top-down' effect, the training will be met with less resistance and the new curriculum will be successfully adopted.

This paper has described one scenario in the current educational landscape in Switzerland. It cannot be assumed that other educational institutes hold the same views or have chosen the same path of action. Yet, considering the fact that the new education policy is being adapted throughout the German-speaking part of Switzerland, the issues will be similar. It remains to be seen how sustainable the effect of competence-based teaching will be for future generations of teachers and learners. A further study in ten years' time would be appropriate to provide more definite information.

11 In German 'Fehlerkultur' where the focus is on what the learner has not yet achieved rather than where he or she stands on their pathway towards learning. 


\section{References}

Ananiadou, K. \& Claro, M. (2009). $21^{\text {st }}$ Century Skills and Competences for New Millenium Learners in OECD Countries. EDU Working paper no. 41. EDU/WKP. Paris: OECD Publishing.

Barr R. B. \& Tagg J. (1995). From Teaching to Learning - A New Paradigm for Undergraduate Education. in Change. The Magazine of Higher Learning 27 (6), 12-26.

Deutschschweizer Erziehungsdirektoren-Konferenz (D-EDK) (2014a). Lehrplan21 - Rahmen-informationen. Luzern: D-EDK Geschäftsstelle.

Deutschschweizer Erziehungsdirektoren-Konferenz (D-EDK) (2014b). Lehrplan21 - Grundlagen. Luzern: D-EDK Geschäftsstelle.

Deutschschweizer Erziehungsdirektoren-Konferenz (D-EDK) (2014c). Lehrplan21 - Medien und Informatik. Luzern: D-EDK Geschäftsstelle.

Deutschschweizer Erziehungsdirektoren-Konferenz (D-EDK) (2015a). Lehrplan21 - Sprachen. Luzern: D-EDK Geschäftsstelle.

Deutschschweizer Erziehungsdirektoren-Konferenz (D-EDK) (2015b). Lehrplan21 - Berufliche Orientierung. Luzern: D-EDK Geschäftsstelle.

Döbeli Honegger, B. \& Neff, C. (2011). Personal Smartphones in Primary School: Devices for a PLE? International Journal of Virtual and Personal Learning Environments, 2 (4), 40-48.

Hutterli, S. (Ed.), (2012). Coordination of Language Teaching in Switzerland. Current Status - Developments - Future prospects. Bern: EDK (Swiss Conference of Cantonal Ministers of Education).

Iten, N. \& Petko, D. (2014). Learning with serious games: is fun playing the game a predictor of learning success? British Journal of Educational Technology. doi: 10.1111/bjet.12226 (accessed 05.04.2015)

Künzli David, C., Bertschy, F., de Haan, G. \& Plesse, M. (2008). Zukunft gestalten lernen durch Bildung für eine nachhaltige Entwicklung. Didaktischer Leitfaden zur Veränderung des Unterrichts in der Primarstufe. Berlin: Freie Universität Berlin.

Lersch, R. \& Schreder, G. (2013). Grundlagen kompetenzorientierten Unterrichtens. Von den Bildungsstandards zum Schulcurriculum. Opladen: Verlag Barbara Budrich.

Muheim, V., Künzli David, C., Bertschy, F. \& Wüst, L. (2014). Bildung für eine nachhaltige Entwicklung vertiefen. Querblicke Grundlagenband. Herzogenbuchsee: Ingold Verlag.

OECD (2013). OECD Skills Outlook 2013: First Results from the Survey of Adult Skills. Paris: OECD Publishing.

Reusser K. (2014). Kompetenzorientierung als Leitbegriff der Didaktik. Beitrag zur Lehrerinnen- und Lehrerbildung, 32 (3), 325-339.

Rychen, D. S., \& Salganik, L. H. (Eds.) (2003). Key Competencies for a Successful Life and a Well-Functioning Society. Göttingen: Hogrefe \& Huber.

Schleicher, A. (Ed.) (2012). Preparing Teachers and Developing School Leaders for the $21^{\text {st }}$ Century: Lessons from around the World. Paris: OECD Publishing.

UNESCO (2014a). Shaping the Future We Want. UN Decade of Education for Sustainable Development (2005-20014). Final report. DESD monitoring and evaluation. Paris: United Nations Educational, Scientific and Cultural Organization

UNESCO (2014b). Roadmap for Implementing the Global Action Programme on Education for Sustainable Development. Paris: United Nations Educational, Scientific and Cultural Organization.

Weinert, F. E. (2001). Vergleichende Leistungsmessung in Schulen - eine umstrittene Selbstverständlichkeit. In: Weinert, F. E. (Hrsg.): Leistungsmessung in Schulen. Weinheim, S. 17-32. 
Internet resources

OECD (2005). The definition and Selection of key Competencies. Executive Summary. Retrieved from http://www.oecd.org/pisa/35070367.pdf

Wildt, J. (2005). Vom Lehren zum Lernen - hochschuldidaktische Konsequenzen aus dem BolognaProzess für Lehre, Studium und Prüfung. Kurzfassung eines Vortrags zur: Expertentagung des EWFT „From Teaching to Learning", Berlin 17.11.2005. Retrieved from: http://www.ewft.de/files/ Wildt-05-Vom\%20Lehren\%20zum\%20Lernen-hochschuldidaktische\%20 Konsequenzen.pdf

\section{Acknowledgement}

The Article is dedicated to Project The VOICE of European TeacherS (VOICES), 526613-LLP2012-NL-Comenius-CNW.

\section{Contact:}

Illya Arnet-Clark, M.A.

Rosemary Smeets-Cowan, M.A.

Jürgen Kühnis, Prof. Dr. Dr.

Pädagogische Hochschule Schwyz

Zaystrasse 41, 6410 Goldau

Switzerland

E-mails: illya.arnet@phsz.ch; rosemary.smeets@phsz.ch; juergen.kuehnis@phsz.ch 